\title{
Rancang Bangun dan Kinerja Irigasi Sprinkler Hand Move Pada Lahan Kering
}

\section{(Design and Performance of Sprinkler Irrigation Hand Move on Dry Land)}

\author{
Fajar $^{1 *)}$, Totok Prawitosari ${ }^{2)}$ dan Ahmad Munir ${ }^{3)}$ \\ ${ }^{1)}$ Program Studi Keteknikan Pertanian Universitas Hasanuddin \\ 2) Program Studi Keteknikan Pertanian Universitas Hasanuddin \\ 3) Program Studi Keteknikan Pertanian Universitas Hasanuddin \\ Email korespondensi: fajartekpert@yahoo.com
}

\begin{abstract}
ABSTRAK
Irigasi adalah pemberian air pada tanaman untuk memenuhi kebutuhan air bagi pertumbuhannya. Lahan kering umumnya berproduksi pada musim hujan dan sangat sulit untuk berproduksi pada musim kemarau, hal ini di karenakan lahan tersebut sangat tergantung pada curah hujan sebagai sumber air bagi tanaman. Teknologi irigasi yang efektif pada lahan kering adalah teknologi irigasi yang dapat mengefisienkan atau menghemat air yakni sistem irigasi sprinkler atau curah. Teknologi irigasi sprinkler atau curah dapat meningkatkan efisiensi penggunaan air irigasi dan keseragaman irigasi yang diberikan lebih dari $85 \%$ dengan sistem yang terpenuhi seperti tekanan, kecepatan angin dan jarak antar sprinkler. Tujuan dari penelitian ini yaitu merancang irigasi sprinkler hand move dan melakukan analisis kinerja sistem irigasi tersebut berdasarkan pengunaan efisiensi sprinkler pada lahan kering. Penelitian ini merancang sebuah alat irigasi sprinkler evaluasi kinerja alat dengan 3 parameter waktu yakni pagi, siang dan sore hari. Hasil nilai koefisien keseragaman (CU) 44,02 - 46,87\% maka dapat diartikan bahwa penyiraman menggunakan sprinkler memiliki keseragaman penyiraman yang kurang baik karena lebih rendah dari $85 \%$, dan begitu pula dengan nilai distribusi keseragaman (DU) yang kurang baik yang berkisar antara 10,99 - 15,54\% memiliki distribusi keseragaman penyiraman yang kurang baik karena lebih rendah dari $25 \%$. Berdasarkan dari hasil nilai koefisien keseragaman (CU) dan nilai distribution uniformit (DU) maka dapat disimpulkan bahwa perancangan kurang efektif dan kurang baik.
\end{abstract}

Kata Kunci: Irigasi, Sprinkler, Lahan Sawah Tadah Hujan.

\section{PENDAHULUAN}

\section{Latar Belakang}

Lahan kering umumnya berproduksi pada musim hujan dan sangat sulit untuk berproduksi pada musim kemarau, hal ini di karenakan lahan tersebut memerlukan sumber airnya tergantung pada curah hujan untuk tanaman. Ketika masuk tahap lahan kering, pada fase kekeringan, tanaman sering mengalami kekurangan sumber air dan memerlukan pasokan air yang memadai untuk pertumbuhan. Energi yang dibutuhkan tanaman berkurang mengakibat produktivitas tanaman menurun.

Daerah lahan kering sebagian besar terdapat tanaman pertanian tetapi sangat sulit untuk sumber air irigasi, dan mengandalkan air hujan sebagai pengairannya. Namun air hujan juga sangat sulit apalagi ketika di daerah lahan kering dan pada saat musim kemarau tiba. Beberapa tahun terakhir ini program ketahanan pangan sangat gencar dilakukan oleh pemerintah, tentu masalah tersebut harus dapat secepatnya ditangani. Untuk 
mengatasi keterbatasan ketersediaan air, perluhnya penanggulangan teknologi irigasi yang hemat air. Sistem irigasi sprinkler atau curah adalah pengelolaan teknologi irigasi yang hemat air. Pada umumnya teknologi irigasi cocok diterapkan pada lahan kering karena membantu pasokan persediaan air pada tanaman.

Teknologi irigasi sprinkler mampu meningkatkan keseragaman irigasi dan penggunaan hemat air irigasi yang disuplai lebih dari $85 \%$ (Tusi, 2016), kehilangan lahan pertanian akibat pembuatan bangunan irigasi dapat diantisipasi dengan baik. Pada kondisi permukaan lahan, baik bergelombang maupun datar kita dapat mengfungsikan sistem irigasi sprinkler. Maka pada lahan kering sistem irigasi ini sangat baik untuk diterapakan. Selain itu, kendala yang dihadapi oleh petani kecil dalam meningkatkan produktivitas tanaman dan pendapatan mereka adalah lemahnya akses untuk mendapatkan teknologi, khususnya teknologi irigasi.

Berdasarkan uraian di atas maka perlu adanya pengembangan teknologi irigasi sprinkler yang mudah digunakan dan dikelola oleh para petani. Penelitian ini bertujuan untuk merancang irigasi sprinkler hand move pada lahan kering dengan berdasarkan pengunaan efisiensi sprinkler.

\section{Tujuan dan Kegunaan}

Tujuan dari penelitian ini yaitu untuk merancang irigasi sprinkler hand move dan melakukan analisis kinerja sistem irigasi tersebut berdasarkan pengunaan efisiensi sprinkler pada lahan kering.

Kegunaan dari penelitian ini yaitu menunjang kemajuan sistem irigasi dan penunjang perkembangan irigasi pada lahan kering

\section{METODOLOGI PENELITIAN}

\section{Alat dan Bahan}

Alat yang digunakan pada penelitian ini yaitu: komputer (dengan kelengkapan software AutoCAD), gergaji potong, las listrik 1 phase, gurinda tangan, stopwatch, katup pipa, pipa PVC 3/4 inchi, sambungan pipa, meteran, selang, kamera, sprinkler impact full circle 3/4 inchi, besi selinder, pressure gauge, catch- can (kaleng), anemometer, gelas ukur, roda sepeda, infiltrometer, dan peralatan bengkel lainnya.

Penelitian ini menggunakan bahan yaitu air.

\section{Prosedur Penelitian}

Prosedur yang dilakukan dalam penelitian prototipe irigasi sprinkler hand move pada lahan sawah tadah hujan. Terdiri dari beberapa bagian yaitu meliputi perancangan konsep desain alat, Prosedur pembuatan prototipe, uji fungsional alat, uji kinerja sprinkler, dan pengolahan dan analisis data.

\section{Perancangan Konsep Desain Alat Uji pendahuluan}

Uji pendahuluan dilakukan untuk menentukan laju penyiraman sprinkler dan infiltrasi tanah. Dimana laju penyiraman yang perluh di ketahui adalah berapa jarak jangkauan siraman sprinkler, tekanan dan waktu yang di butuhkan, sedangkan infiltrasi yaitu diketahui bagaimana daya serap tanah terhadap air.

\section{Mengukur Laju Infiltrasi}

Adapun prosedur yang dilakukan pada pengukuran Infiltrasi dengan infiltrometer sebagi berikut:

1. Menentukan lahan

2. Memasang double ring pada lahan yang akan diukur

3. Mengukur tinggi double ring

4. Memasukan air kedalam double ring menggunakan penahan air dengan kedalaman $8 \mathrm{~cm}$.

5. Melepaskan penahan air kemudian mengukur penurunan air dengan menggunakan stopwatch dan meteran

6. Mencatat waktu penurunan air setiap $1 \mathrm{~cm}$

7. Melakukan pengambilan sampel 3 titik

8. Mengolah data dengan menggunakan persamaan sebagai berikut (Undang, 2006).

$$
v=\frac{w}{t}
$$

Keterangan: 
$v=$ kecepatan $(\mathrm{m} / \mathrm{det})$

$w=\operatorname{jarak}(\mathrm{m})$

$t=$ waktu (det)

\section{Laju Penyiraman}

Adapun prosedur yang dilakukan pada laju penyiraman sebagi berikut:

1. Menentukan lahan

2. Memasang sprinkler pada lahan yang sudah ditentukan

3. Memasang selang penghubung dari pompa ke sprinkler

4. Meletakkan catch can dengan jarak 1 meter sebanyak 225 buah

5. Mengoperasikan sistem irigasi sprinkler dalam 35 menit kemudian diukur:

a. Debit pada sprinkler

b. Volume air tertampung dalam catch can

c. Diameter kaleng

d. Tekanan

e. Jarak pancaran (jangkauan terjauh)

6. Mengolah data

7. Menghitung debit air pada sprinkler dengan rumus :

$$
\mathrm{Q}=\mathrm{V} / \mathrm{T}
$$

Keterangan :

$\mathrm{Q}=\operatorname{debit}(\mathrm{L} / \mathrm{detik})$

$\mathrm{V}=$ volume (Liter)

$\mathrm{T}=$ waktu (detik)

\section{Analisis Rancangan}

Alat irigasi curah (sprinkler) ini menggunakan beberapa komponan yaitu: sprinkler, pipa PVC $3 / 4$, pressure gauge, roda, dan selang. Alat ini direncanakan menggunakan jenis sprinkler impact full circle $3 / 4$ inchi dengan spesifikasi sprinkler radius siram: $7 \mathrm{~s} / \mathrm{d} 15 \mathrm{~m}$, tekanan kerja: $2 \mathrm{~s} / \mathrm{d}$ 4.5 bar, derajat siram: 360 derajat, debit siram: 11 s/d 54 liter/menit. Ada 2 sprinkler yang digunakan dengan harapan pancaran siraman overlay. Kemudian ada 2 roda yang diharapan dapat menopang pipa dan sprinkler. Dan 1 roda sebagai penyeimbang alat ketika beroperasi.

\section{Rancangan Fungsional}

Fungsi utama dari alat irigasi curah (sprinkler) pada lahan sawah tadah hujan adalah untuk menyirami atau menyemprot air ke tanaman yang membutuhkan pasokan air sebagai upaya penyuplai air ketika musim kemarau tiba.

Rangka Unit Penyiraman. Diharapkan dapat berfungsi sebagai penopang beban air yang disemprotkan dari sprinkler ketika berputar dan memiliki tekanan air tertentu dan dapat menjaga keseimbangan agar tetap tegak serta roda yang dapat berfungsi sebagai penopang ketika beroperasi dan dipindahkan ke lateral yang lain. Lahan yang permukaannya tidak rata menyulitkan roda berpindah dan selalu menjaga keseimbangan tegak unit penyemprotan.

Sprinkler, berfungsi untuk menyemprot air ke lahan. Jenis sprinkler yang digunakan adalah sprinkler impact full circle $3 / 4$ inchi dengan spesifikasi sprinkler radius siram: 7 s/d 15 meter, tekanan kerja: 2 s/d 4.5 Bar, derajat siram: 360 derajat, debit Siram: 11 s/d 54 liter/menit.

Selang, berfungsi untuk menyalurkan air dari sumber air ke pipa penyalur menuju sprinkler. Jenis selang yang digunakan adalah selang benang $3 / 4$ inchi.

Roda, berfungsi sebagai penopang ketika beroperasi dan dipindahkan ke lateral yang lain.

Pipa, berfungsi sebagai penyalur air dari selang ke sprinkler, pipa ini di pasang di unit penyiraman. pipa yang digunakan adalah pipa pvc $3 / 4$ inchi.

Pressure gauge, berfungsi sebagai pengatur tekanan air yang dibutuhkan untuk penyiraman tanaman.

Anemometer, berfungsi menghitung kecepatan angin.

\section{Rancangan Struktural}

Alat Penyiram terbuat dari besi silinder, desain rangka yang terdiri dari pipa pvc $3 / 4$, besi silinder sebagai dudukan pipa, panjang pipa disesuaikan dengan jarak antar sprinkler, jarak sprinkler beracuh pada profil siraman pada laju penyiraman uji pendahuluan. kemudian ada 3 roda sebagai penopang dengan tinggi 50 centimeter, 1 buah besi silinder penghubung antar roda, panjang besi tersebut 7 meter dan 1 roda sebagai penyeimbang yang teretak dibelakang unit dengan berjari-jari 10 centimeterm. Serta ada klem pipa sebagai pengikat pipa dengan besi silinder. 


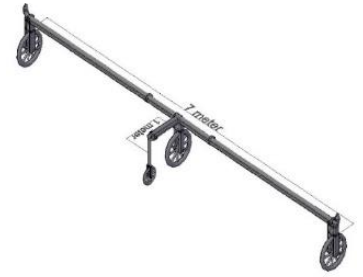

Gambar 1. Desain Alat Penyiram

\section{Dasar Rancangan}

Rancang alat irigasi sprinkler hand move dengan pertimbangan dan berdasarkan pada uji pendahuluan yang dilakukan dengan jarak antar sprinkler 7 meter dengan pertimbangan pola tanam 40x20 centimeter untuk tanaman kacang tanah dan tekanan yang diberikan pada uji pendahuluan 2 bar dengan jarak siraman 7 meter dari sprinkler itu sendiri.

\section{Prosedur Pembuatan prototipe}

Setelah semua komponen dibuat maka tahap selanjutnya adalah merakit komponen tersebut menjadi irigasi sprinkler hand move. Berikut tahapan pembuatan prototipe:

1. Siapkan alat dan bahan,

2. Potong besi silinder sesuai dengan yang dibutuhkan,

3. Besi yang telah di potong di satukan dengan cara di las sehingga menjadi rangka unit,

4. Memasang dan menghubungkan roda dengan besi silinder mengunakan bearing,

5. Memasang pipa ke besi silinder dengan mengunakan klem, dan memasang baut dan mor di penghubung penopang pipa.

6. Memasang sprinkler dan selang.

\section{Uji fungsional}

Uji fungsional merupakan bagian dari proses pembuatan alat ini. Pada proses ini yang dilakukan yaitu mengecek semua sambungan tiap alat dan setiap komponen berfungsi tidaknya, agar tidak terjadi kesalahan dalam pengoperasian Alat dilahan.

\section{Pengukuran Kinerja Irigasi Sprinkler}

Prosedur pengukuran kinerja irigasi sprinkler adalah :

1. Mempersiapkan alat dan bahan tersebut, serta memasangnya dalam suatu rangkaian
2. Meletakkan catch can disekitar daerah yang sudah di plot yang dengan jarak 1 meter sebanyak 198 buah

3. Mengoperasikan sistem irigasi sprinkler dalam 35 menit kemudian diukur:

a. Debit pada sprinkler

b. Volume air tertampung dalam catch can

c. Diameter kaleng

d. Tekanan

e. Jarak pancaran (jangkauan terjauh)

f. Kecepatan angin

5. Mengulang kembali pengukuran yang dpilakukan sebanyak 3 kali pada 3 parameter waktu yaitu pagi,siang dan sore hari.

\section{Pengolahan dan Analisis Data}

Analisi Data Kinerja Irigasi Sprinkler

1. Parameter yang diamati

a. Tebal air tertampung tiap satuan waktu

b. Debit.

c. Jarak pancaran

d. Tekanan operasi yang dibaca pada pressure gauge.

2. Tingkat keseragaman penyebaran air dinilai dengan menggunakan indeks $\mathrm{CU}$ (coefficient uniformity) yang dinyatakan dengan rumus :

$$
\mathrm{CU}=100\left[1-\frac{\Sigma(X i-X)}{x i}\right]
$$

Keterangan:

$\mathrm{CU}=$ Koefisien keseragaman $(\%)$

$\mathrm{Xi}=$ Nilai masing-masing pengamatan $(\mathrm{cc})$

$\mathrm{X}=$ Nilai rata-rata pengamatan (cc)

$\boldsymbol{\Sigma}(\mathrm{Xi}-\mathrm{x})=$ Jumlah tiap pengamatan dibagi dengan jumlah total pengamatan (cc)

3. Tingkat Distribusi penyebaran air dinilai dengan menggunakan indeks DU (distribution uniformit) yang dinyatakan dengan rumus :

$$
\text { DU }=100-1,59(100-C U)
$$

4. Laju aplikasi

$$
\mathrm{I}=\frac{60 \times q}{\operatorname{SexSl}}
$$

dimana :

I : laju penyiraman rata-rata (milimeter/jam)

$\mathrm{K}$ : faktor konversi sebesar 60

$\mathrm{q}$ : debit sprinkler 
Se : jarak sprinkler dalam lateral (meter)

$\mathrm{S} 1$ : jarak antar lateral (meter)

\section{Bagan Alir Prosedur Penelitian}

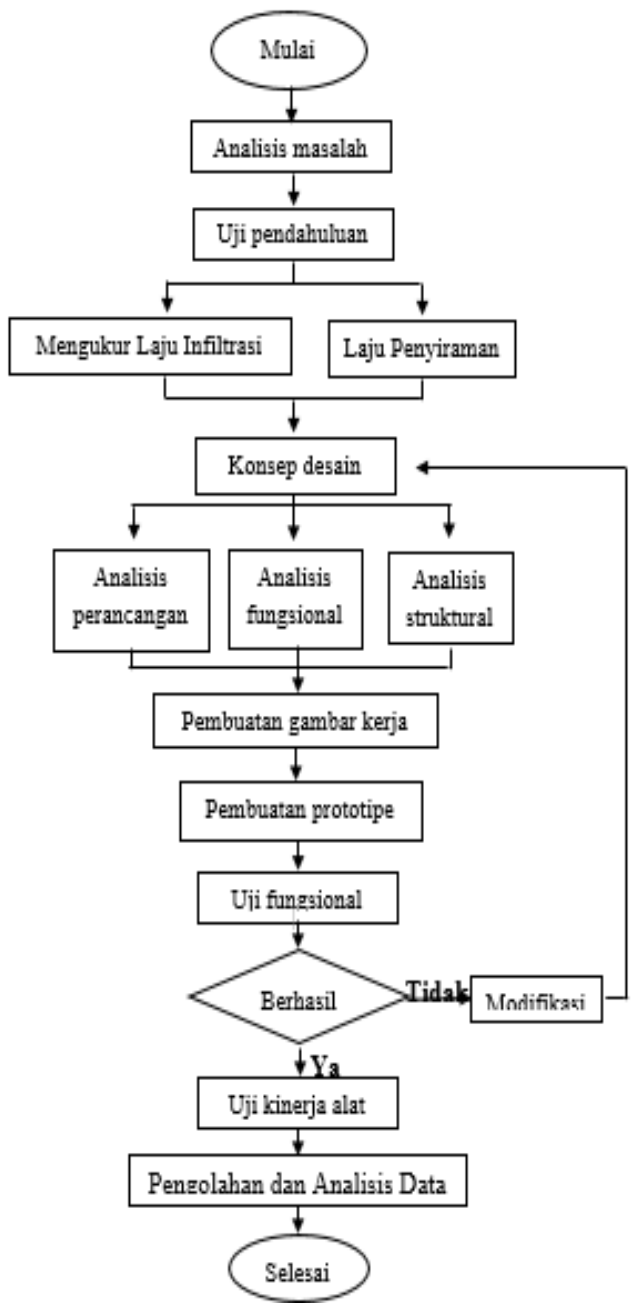

Gambar 2. Diagram Alir Penelitian

\section{HASIL DAN PEMBAHASAN}

Alat irigasi sprinkler hand move

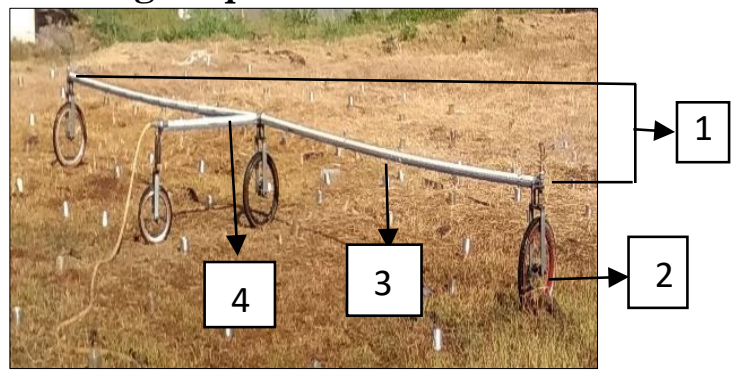

Keterangan

1. Sprinkler

2. Roda

3. Besi hollow $2 \times 4$

4. Pipa PVC $3 / 4$ inchi

Gambar 3. Alat Irigasi Sprinkler Hand Move

Rancang alat irigasi sprinkler hand move pada analisis perancangan alat irigasi curah (sprinkler) direncanakan menggunakan jenis sprinkler impact full circle $3 / 4$ inchi dengan spesifikasi sprinkler Radius Siram: 7 s/d 15 meter, tekanan kerja: 2 s/d 4.5 bar, derajat siram: 360 derajat, debit siram: 11 s/d 54 liter/menit. Pengujian alat digunakan tekanan yang digunakan 2 bar. Ada 2 sprinkler yang digunakan dengan harapan pancaran siraman overlay. Kemudian ada 2 roda yang diharapan dapat menopang pipa dan sprinkler. Dan 1 roda sebagai penyeimbang alat ketika beroperasi.

Rancang analisis fungsional menganalisis perancangan menggunakan beberapa komponen, komponen yaitu sprinkler itu sendiri, piva PVC $3 / 4$ inchi sepanjang 7 meter untuk diletakkan di penghubung sprinkler dan penyalur air ke sprinkler, besi hollow sebagai rangka utama alat, dan 3 roda sebagai penopang alat ketika beroperasi dan dipindahkan ke lateral yang lain dan 1 roda berjari $10 \mathrm{~cm}$ berfungsi sebagai penyeimbang alat dan pengarah alat tersebut yang mampu berputar 360 derajat.

Rancang analisis struktural alat penyiram terbuat dari besi silinder, desain rangka yang terdiri dari pipa pvc 3/4, besi silinder sebagai dudukan pipa, panjang pipa disesuaikan dengan jarak antar sprinkler, jarak sprinkler beracuh pada profil siraman pada laju penyiraman uji pendahuluan yakni 7 meter. kemudian ada 3 roda sebagai penopang dengan tinggi 50 centimeter, 1 buah besi silinder penghubung antar roda, panjang besi tersebut 7 meter dan 1 roda sebagai penyeimbang yang teretak dibelakang unit dengan berjari-jari $10 \mathrm{~cm}$. Serta ada klem pipa sebagai pengikat pipa dengan besi silinder.

\section{Hasil Uji pendahuluan Profil Siraman Uji Pendahuluan}

Untuk mengetahui penyebaran siraman yang tertampung pada catch can yang di letakkan dengan jarak 1 meter pada uji pendahuluan oleh sprinkler impact full circle $3 / 4$ inchi dapat dilihat pada grafik profil siraman berikut ini: 


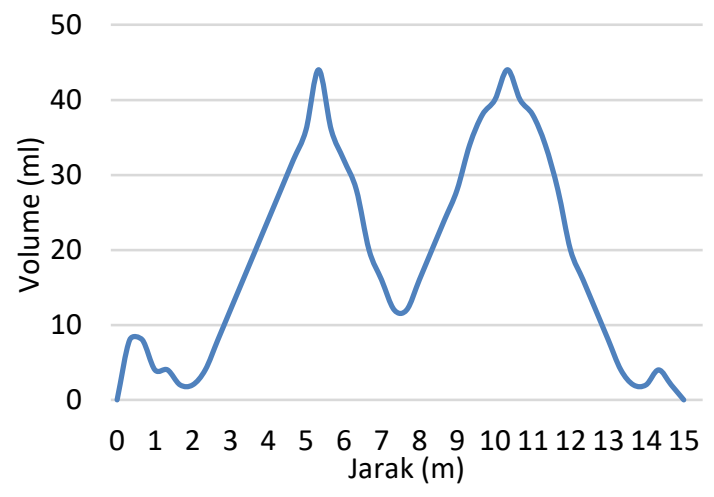

Gambar 4. Grafik profil siraman pendahuluan

Pada grafik profil siraman pendahuluan dapat terlihat pada volume dan tingkatan penyiraman air di berikan suatu tekanan dan sprinkler itu sendiri. Pola distribusi dari sebuah tekanan 2 bar yang diberikan yaitu pola tekanan terlalu rendah. Hal ini sesuai denga pendapat Khairiah (2014), yang menyatakan bahwa volume dan tingkatan penyiraman air diberikan pada sprinkler secara normal dengan berbagai variasi antar jarak antar sprinkler yang diterapkan. Pola tersebut disebut dengan pola distribusi, konsisten secara normal untuk sebuah tekanan, bentuk nozzle, dan angin ketikan beroperasi. Pola-pola disribusi penyiraman disemprot sebuah single sprinkler dengan bentuk nozzle yang tetap dan tekanan yang berbeda-beda diberikan pada suatu operasi sprinkler.

\section{Hubungan Aplikasi dan Infiltrasi}

Laju infitrasi yaitu kapasitas laju atau penurunan aliran air di dalam tanah sedangkan laju aplikasi yaitu pemberiaan air yang pancarkan oleh sprinkler. Pada sistem irigasi sprinkler didesain kurang dari kapasitas laju infiltrasi dalam tanah dengan laju aplikasi yang di berikan agar tidak terjadi aliran permukaaan. Hal ini sesuai dengan pendapat Khairiah (2014), yang menyatakan bahwa secara normal, sistem irigasi sprinkler didesain sehingga tidak terjadi aliran permukaan. Kemudian laju aplikasi pada tingkat dimana sebuah sistem sprinkler didesain untuk memakai air kurang dari kapasitas infiltrasi dari tanah atau pengaplikasian diakhiri sebelum seluruh permukaan tanah yang dangkal terisi dengan air dan kedalaman air yang cukup untuk menyebabkan aliran permukaan di atas permukaan tanah terakumulasi.

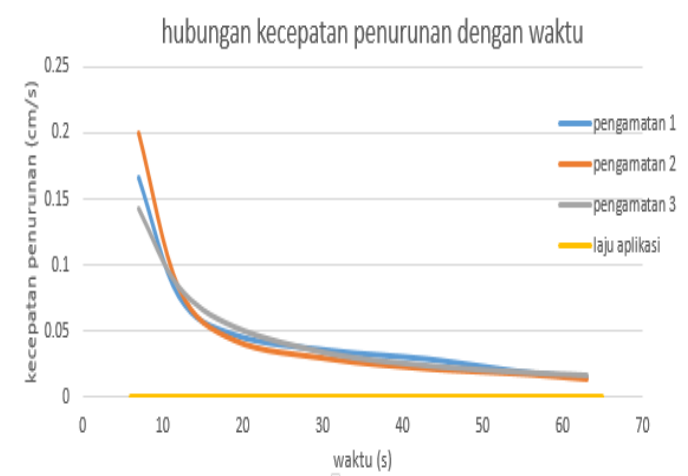

Gambar 5. Grafik Hubungan Laju aplikasi dan Laju Infiltrasi

Pengamatan 1, 2 dan 3 pada gambar diatas merupakan pengamatan laju infiltrasi dimana laju infitrasi tersebut pada awal penurunannya cepat atau kapasitas infiltrasinya paling tinggi kemudian terjadi pelambatan atau berkurang terus menerus. hal ini sesuai dengan pendapat Khairiah (2014), yang menyatakan bahwa kapasitas infiltrasi dari tanah yang paling tinggi adalah pada waktu awal infiltrasi dan kemudian berkurang secara terus-menerus dengan waktu ke arah sebuah asimtot yang sering disebut tingkat infiltrasi dasar dari tanah. Dalam sebuah tanah homogen yang sangat dalam, tingkat infiltrasi dasar sama dengan konduktivitas hidrolik jenuh dari air

Berdasarkan pengamatan 1, 2 dan 3 laju infitrasi masuk klasifikasi sangat cepat karena $>250 \quad \mathrm{~mm} / \mathrm{jam}$ kecepatan penurunannya. Mengingat laju aplikasi yang di tunjukkan pada garis horizontal pada gambar 4 terlihat laju aplikasi tersebut lebih besar dari kapasitas infiltrasi air dalam tanah, Maka aliran permukaan tidak terjadi. Garis horizontal menunjukkan sebuah sistem laju aplikasi tidak pernah melebihi kapasitas infiltrasi di dalam tanah. Hal ini sesuai dengan pendapat Khairiah (2014), Pada awalnya semua air yang diaplikasikan oleh sistem sprinkler memasuki tanah, karena laju aplikasi lebih besar dari kapasitas infiltrasi tanah. Aliran permukaan tidak terjadi sampai garis B melintasi garis A dan laju aplikasi melebihi kapasitas 
infiltrasi dari tanah. Aliran permukaan mulai terjadi jika turunan-turunan pada permukaan tanah terisi oleh air dan kedalaman air yang cukup untuk menyebabkan aliran terakumulasi pada permukaan tanah. Jumlah air yang dapat terakumulasi bergantung kepada kondisi seperti jumlah vegatasi atau kedalaman turunan.

\section{Evaluasi Kinerja Jaringan Irigasi Sprinkler Hand Move}

Pada evaluasi sebaran sprinkler hand move terdiri dari koefisien keseragaman dan distribusi keseragaman. Dimana pada pengujian evaluasi menggunakan 2 jenis sprinkler impact full circle $3 / 4$ inchi dan 198 catch can yang tersebar seperti pada gambar 5 dibawah,

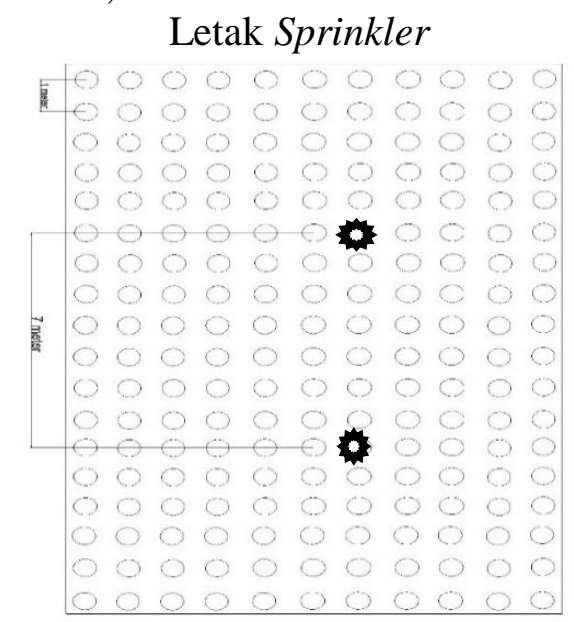

Keterangan :

O catch can

Sprinkler

Gambar 6. Layout Jaringan Letak sprinkler

Pengujian menunjukkan tekanan 2 bar dan radius pancaran 7 meter pada saat pengujian pendahuluan. Kondisi tersebut sesuai dengan radius 1 meter sehingga memungkinkan setiap memnuhi kebutuhan air pada 198 catch can dengan 2 sprinkler.

Evaluasi kinerja sprinkler sangat dipengaruhi oleh tekanan dari pompa, kecepatan angin ketika beroperasi, jarak sprinkler, dan topografi lahan. Semakin tinggi tekanan pompa menyebabkan air yang keluar dari nozel pada sprinkler menjadi merata selama masih dalam spesifikasi sprinkler tersebut. Kecepatan angin menyebabkan butiran air yang keluar dari nozel sprinkler akan terbawa.

Tabel 1. Hasil perhitungan Nilai Koefisien Keseragaman (CU) (\%),

\begin{tabular}{ccccr}
\hline CU & $\mathbf{1}$ & $\mathbf{2}$ & $\mathbf{3}$ & rata-rata \\
\hline Pagi & 46,90 & 48,94 & 44,79 & 46,88 \\
Siang & 43,81 & 46,02 & 42,22 & 44,02 \\
Sore & 51,35 & 40,74 & 41,67 & 44,59 \\
\hline
\end{tabular}

Debit $=1.200 \mathrm{~L} / \mathrm{Jam}$

laju Aplikasi $=1.469,39 \mathrm{~cm} / \mathrm{Jam}$

Tabel 2. Hasil perhitungan Nilai Distribusi Keseragaman (DU) (\%),

\begin{tabular}{ccccc}
\hline DU & $\mathbf{1}$ & $\mathbf{2}$ & $\mathbf{3}$ & Rata-rata \\
\hline Pagi & 15,58 & 18,81 & 12,22 & 15,54 \\
Siang & 10,67 & 14,18 & 8,12 & 10,99 \\
Sore & 22,65 & 5,78 & 7,26 & 11,90 \\
\hline
\end{tabular}

\begin{tabular}{cccc} 
Sore 22,65 & 5,78 & 7,26 & 11,90 \\
\hline Hasil perhitungan & nilai & koefisien
\end{tabular}

keseragaman (CU) menggunakan persamaan 3 waktu pagi, siang dan sore yang berbeda terjadi perbedaan. Nilai koefisien keseragaman tertinggi diproleh pada pagi hari dengan rata-rata sebesar 46,88\% dan terendah pada siang hari dengan rata-rata sebesar $44,02 \%$. Dengan hasil perhitungan nilai koefisien keseragaman (CU) 44,02 - 46,88\% maka dapat diartikan bahwa penyiraman menggunakan sprinkler memiliki keseragaman penyiraman yang kurang baik karena lebih rendah dari $85 \%$. Hal ini sesuai dengan pendapat Khairiah (2014), menyatakan bahwa efisiensi sprinkler tergolong tinggi (keseragaman tergolong baik) apabila presentasinya lebih besar dari $80 \%$. Nilai koefisien yang kecil menunjukkan sistem irigasi tersebut kurang baik dalam pemberian air yang seragam pada masing-masing tanaman, sehingga tanaman akan menerima air dalam jumlah yang tidak sama.

Berdasarkan Tabel 2. Diketahui nilai keseragaman distribusi terbesar pada pagi hari yaitu $15,54 \%$. kemudian diikuti oleh sore hari sebesar $11,90 \%$ dan siang hari sebesar $10,99 \%$. dengan hasil perhitungan nilai distribusi keseragaman (DU) yang berkisar antara 10,99 - 15,54\%, maka dapat diartikan bahwa penyiraman menggunakan sprinkler memiliki distribusi keseragaman yang kurang baik. 
Perbedaan nilai koefisien keseragaman dan distribusi keseragaman untuk 3 parameter waktu yaitu pada pagi hari nilai koefisien keseragaman dan distribusi keseragaman lebih besar dibandingkan dengan nilai koefisien keseragaman dan distribusi keseragaman pada siang dan sore hari. Hal ini dipengaruhi oleh tekanan, dan kecepatan angin yang terjadi pada lokasi penelitian.

Tekanan 2 bar dan jarak antara selang lateral dari pompa ke sprinkler mencapai 25 meter mempengaruhi jarak siraman lemparan. Semakin besar jarak semakin besar pula tekanan tekanan yang dibutuhkan. Hal ini sesuai dengan pendapat Prijono (2013), yang menyatakan bahwa jarak bertambah bila kemampuan melempar sprinkler naik hal ini dipengaruhi tekanan operasi.

Kecepatan angin pada pada sore hari mencapai 1,3 $-1,9 \mathrm{~m} / \mathrm{s}$ lebih tinggi dibandingkan angin pada pagi hari dan siang hari, sehingga butiran air yang lebih kecil mengalami evaporasi dan terbawa tiupan angin. Hal ini sesuai dengan pendapat Prijono (2013), yang menyatakan bahwa butiran yang lebih kecil umumnya jatuh dekat sprinkler sedangkan yang lebih besar jatuh lebih jauh. Ukuran butir yang besar dapat merugikan pada tanaman (terutama sayuran) dan menyebabkan erosi percik yang akhirnya terjadi pemadatan tanah, sedangkan ukuran butiran yang terlalu kecil akan mudah menguap sehingga banyak air terbuang dan akibatnya efisiensi irigasi menjadi rendah. Ukuran butiran yang diinginkan dapat dikendalikan dengan mengatur ukuran nozel dan tekanan operasional. Perbedaan nilai keseragaman pemberian air dapat dilihat pada gambar berikut ini :

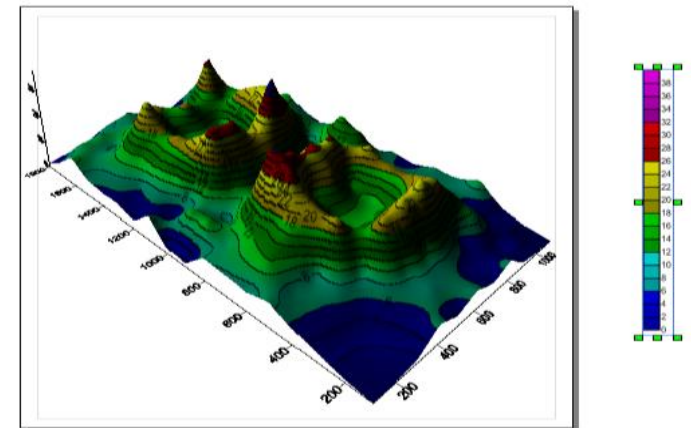

Gambar 7. Kontur 3 Dimensi Keseragaman Pemberian Air pagi hari

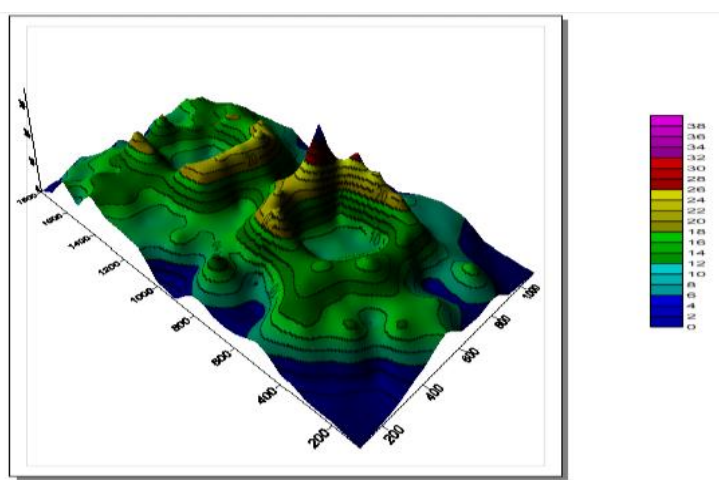

Gambar 8. Kontur 3 Dimensi Keseragaman Pemberian Air Siang hari

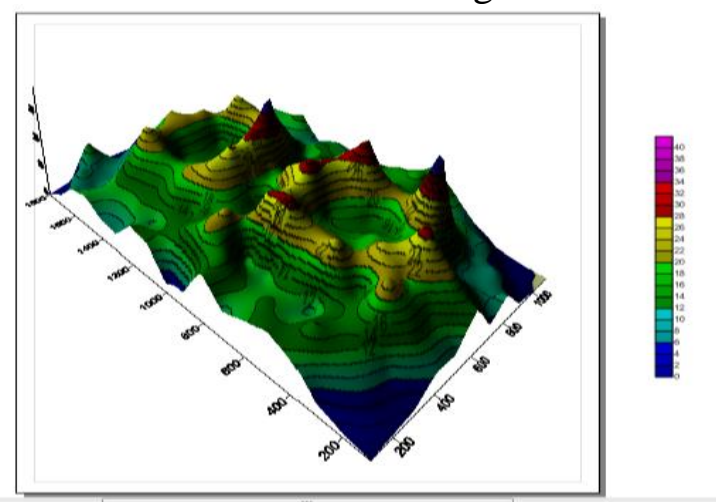

Gambar 9. Kontur 3 Dimensi Keseragaman

Pemberian Air Sore hari.

Surfer yakni menghubungkan garis yang nilai tinggi rendahnya dan nilainya sama seperti yang terdapat pada gambar kontur 3 dimensi keseragaman pemberian air di atas. Pada gambar 6 dimana nilai garis di tentukan dengan volume air yang tertampung di catch can mulai dari nilai 0 sampai $38 \mathrm{ml}$, gambar 7 dimana nilai 0 sampai $38 \mathrm{ml}$ dan gambar 8 dimana nilai 0 sampai $40 \mathrm{ml}$. Dari 3 gambar warna yang lebih dominan yaitu warna biru dan hijau. catch can yang jauh dari sprinkler nilai volume air yang tertampung dominan rendah dibandingkan dengan catch can yang 
berada di dekat sprinkler hal ini disebabkan karena butiran air yang tersemprot di catch can lebih kecil dan juga dipengaruhi oleh kecepatan angin, tetapi ada sebagian nilai volume air catch can rendah di dekat sprinkler hal ini disebabkan karena adanya tiupan angin di catch can pada saat pengujian.

\section{Profil Siraman}

Perbedaan nilai koefisien keseragaman dan distribusi keseragaman untuk 3 parameter waktu. Hal ini dipengaruhi oleh tekanan, arah dan kecepatan angin. Pompa yang digunakan pompa shimizu tipe ps-135E dengan tekanan 2 bar. Tekanan pada pompa tentunya berbeda dengan tekanan yang sampai di sprinkler. Untuk mengetahui masing-masing tekanan pada yang di pancarkan oleh Sprinkler impact full circle 3/4 inchi dapat dilihat pada Grafik profil siraman berikut ini:

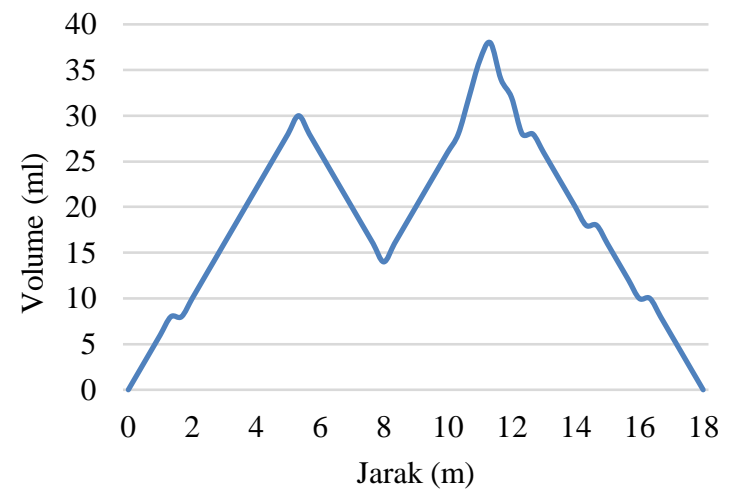

Gambar 10. Grafik profil siraman horizontal pagi hari

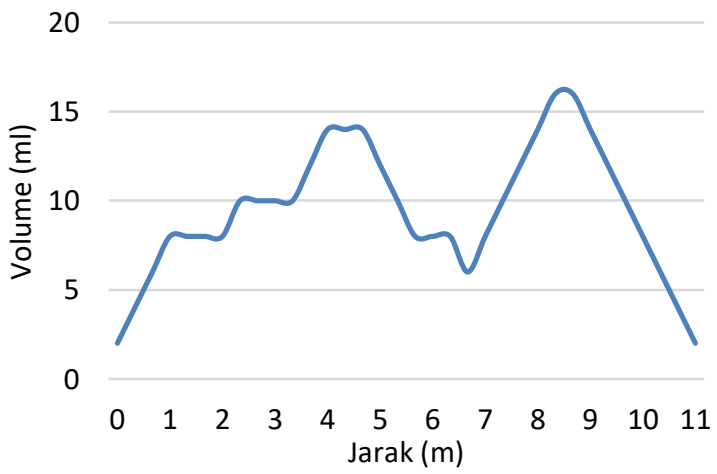

Gambar 11. Grafik profil siraman vertikal pagi hari

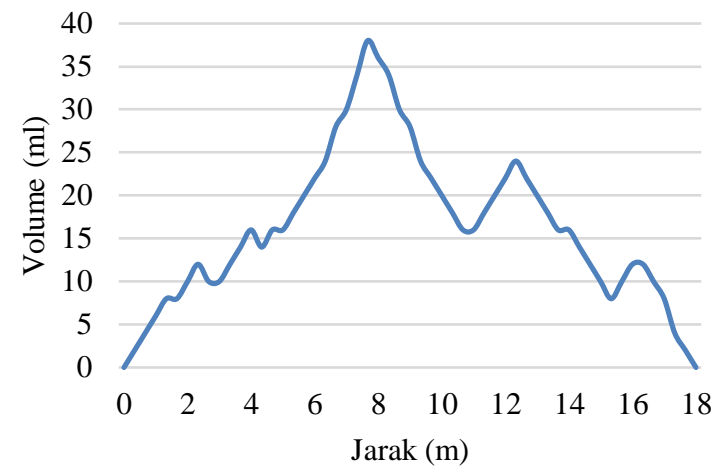

Gambar 12. Grafik profil siraman horizontal siang hari

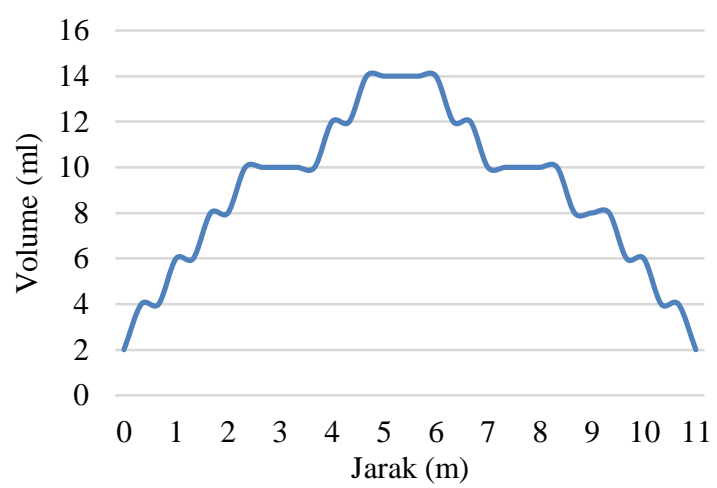

Gambar 13. Grafik profil siraman vertikal siang hari

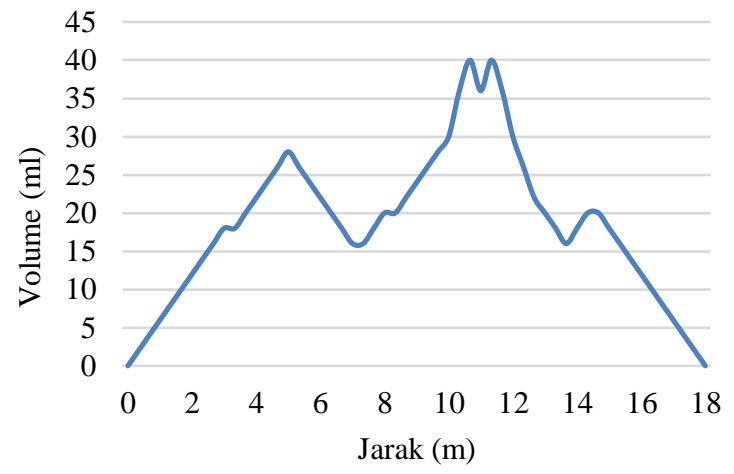

Gambar 14. Grafik profil siraman horizontal sore hari

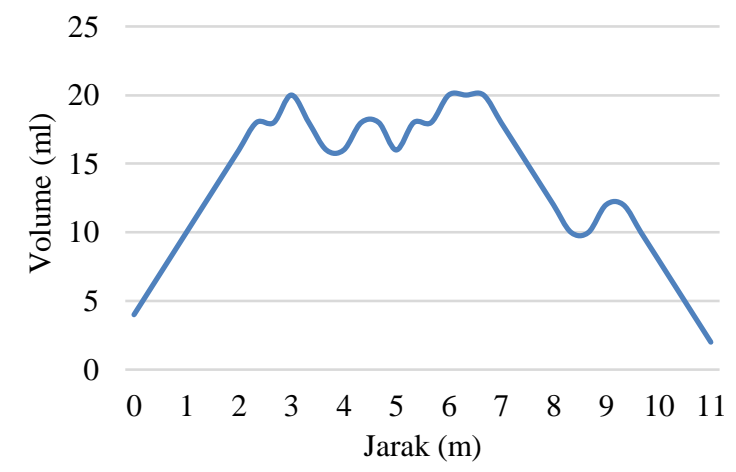

Gambar 15. Grafik profil siraman vertikal sore hari 
Pola distribusi pada grafik profil siraman horizontal pagi hari terlihat perbedaan distribusi air yang kurang merata karena terlihat pada grafiknya di setiap jarak dengan volumenya. Pola distribusi dari volume air yang tertampung tidak merata terlihat pada profil siraman ini, di jarak 11,5 $\mathrm{m}$ lebih dominan volume $38 \mathrm{ml}$ di banding dengan di jarak-jarak yang lain. Pola distribusi ini terlihat overlay di jarak antara $7 \mathrm{~m}$ sampai $12 \mathrm{~m}$. dan distribusi siraman jarak 11,5 m merupakan volume yang paling tinggi karena overlay yang banyak antara siraman sprinkler 1 dan sprinkler yang ke 2 . Grafik profil siraman vertikal pagi hari yaitu terlihat overlay yang tampak dari volume 2 $\mathrm{ml}$ di jarak $0 \mathrm{~m}$ naik hingga volume $14 \mathrm{ml}$ di jarak 4 sampai $5 \mathrm{~m}$, kemudian turun hingga volume $6 \mathrm{ml}$ di jarak $7 \mathrm{~m}$, kemudian naik hingga volume $16 \mathrm{ml}$ di jarak $8,5 \mathrm{~m}$ kemudian turun lagi sampai volume $2 \mathrm{ml}$ di jarak $11 \mathrm{~cm}$.

Pola distribusi dari volume air yang tertampung tidak merata terlihat pada grafik profil siraman horizontal siang hari, di jarak 7,5 $\mathrm{m}$ lebih dominan volume $38 \mathrm{ml}$ di banding dengan di jarak-jarak yang lain. Pola distribusi ini terlihat overlay di jarak antara $7 \mathrm{~m}$ sampai $12 \mathrm{~m}$, dan distribusi siraman jarak $7,5 \mathrm{~m}$ merupakan volume yang paling tinggi karena overlay yang banyak antara siraman sprinkler 1 dan sprinkler yang ke 2. Grafik profil siraman vertikal siang hari yaitu terlihat overlay yang tampak dari volume $2 \mathrm{ml}$ di jarak $0 \mathrm{~m}$ naik hingga volume $14 \mathrm{ml}$ di jarak 5 sampai $6 \mathrm{~m}$, kemudian turun hingga volume $10 \mathrm{ml}$ di jarak $7 \mathrm{~m}$, kemudian netral hingga jarak 8,5 $\mathrm{m}$ kemudian turun lagi sampai volume $2 \mathrm{ml}$ di jarak $11 \mathrm{~m}$.

Pola distribusi dari volume air yang tertampung tidak merata terlihat pada grafik profil siraman horizontal sore hari, di jarak 10,5 sampai 11,5 m lebih dominan volume $40 \mathrm{ml}$ di banding dengan di jarak-jarak yang lain. Pola distribusi ini terlihat overlay di jarak antara $7 \mathrm{~m}$ sampai $12 \mathrm{~m}$. dan distribusi siraman jarak 10,5 sampai 11,5 m merupakan volume yang paling tinggi karena overlay yang banyak antara siraman sprinkler 1 dan sprinkler yang ke 2. Grafik profil siraman vertikal siang hari yaitu terlihat overlay yang tampak dari volume 4 $\mathrm{ml}$ di jarak $0 \mathrm{~m}$ naik hingga volume $20 \mathrm{ml}$ di jarak $3 \mathrm{~m}$, kemudian turun naik dengan volume 16 sampai $20 \mathrm{ml}$ dari jarak 3 jarak sampai $7 \mathrm{~m}$, kemudian netral hingga jarak $8,5 \mathrm{~m}$ kemudian turun lagi sampai volume 2 $\mathrm{ml}$ di jarak $11 \mathrm{~m}$

Pola distribusi yang terlihat pada profil siraman dengan volume jumlah air di semprot suatu sprinkler yang banyak beragam variasi dengan jarak antar sprinkler dan tekanan yang diberikan. Grafik siraman yang terdapat dimulai dari titik awal nol sampai titik ujung jangkauan siraman sprinkler, perbedaan grafik dari 3 parameter waktu yang berbeda profil siramannya ini dipengaruhi oleh tekanan dan kecepatan angin. Berdasarkan 3 grafik profil siraman di atas maka dapat disimpulkan bahwa pola bervarasi atau pola distribusi dari sprinkler impact full circle 3/4 inchi yakni tekanan terlalu rendah.

\section{KESIMPULAN}

Adapun kesimpulan dari penelitian ini yaitu:

1. Hasil nilai koefisien keseragaman (CU) ysng didapat pada penelitian irigasi sprinkler hand move berkisar 44,02 $46,88 \%$, menunjukkan bahwa hasil tersebut kurang dari $85 \%$ dan hasil nilai dari distribusi keseragaman (DU) berkisar 10,99 - 15,54\%, menunjukkan bahwa hasil tersebut kurang dari $25 \%$. pernyataan ini menunjukkan tingkat pemberian distribusi air kurang merata.

2. Alat irigasi sprinkler hand move ini kurang efektif untuk digunakan pada lahan sawah tadah hujan karena beberapa faktor yang mempengaruhi yaitu tekanan, kecepatan angin dan peletakan antar sprinkler itu sendiri. 


\section{DAFTAR PUSTAKA}

Khairiah N. I, 2014 Evaluasi Kinerja Penggunaan Air Irigasi Sprinkler Studi Kasus Di Kabupaten Enrekang. Universitas Hasanuddin Makassar.

Prijono, Sugeng. 2013. Sejarah, Fungsi dan Perundangan Irigasi. http://docplayer.info/54313796-Isejarah-fungsi-dan-perundanganirigasi.html. Diakses pada Sabtu, 09 September 2017, pukul 14.57 WITA.

Tusi A., Lanya Budianto. 2014. Rancangan Irigasi Sprinkler Portable Tanaman Pakchoy. Lampung Universitas Lampung. 